\title{
Effects of algal diet on the performance and susceptibility to predation of the sea hare Aplysia parvula
}

\author{
Cary N. Rogers*, Rocky de Nys, Peter D. Steinberg \\ School of Biological Science, University of New South Wales, New South Wales 2052, Australia
}

\begin{abstract}
Although sea hares are well known for acquiring algal secondary metabolites from their diet, the effects of diet on fitness and the susceptibility of sea hares to predators are poorly understood. We examined the effects of diet on the performance of the sea hare Aplysia parvula, and measured predation by reef fishes on sea hares raised on different seaweeds. Diet-switching, body size, the presence of conspecifics, and the presence of epiphytes on dietary algae were also investigated experimentally. A. parvula were fed the chemically rich red algae Delisea pulchra or Laurencia obtusa in laboratory experiments, and consumption, growth, egg production, conversion efficiency, and survivorship were measured. Sea hares fed L. obtusa consumed more algae, grew faster, laid more eggs, and had higher survivorship compared to sea hares fed D. pulchra. Most other factors investigated-body size, the presence of conspecifics or epiphytes-were in general unimportant relative to the effects of diet. The disparity in fitness of $A$. parvula fed $D$. pulchra versus $L$. obtusa is primarily due to different levels of consumption of each seaweed, as conversion efficiencies were similar. Predation on sea hares raised on different diets and containing different types and levels of acquired secondary metabolites was measured in field experiments in which sea hares were exposed to mixed assemblages of reef fishes. A high proportion of both chemically rich (fed red algae) and chemically poor sea hares (fed the green alga Ulva sp.) were eaten by fishes (with predation rates of 25 to $55 \%$ over 1 to $2 \mathrm{~h}$ ), although this sea hare was relatively unpalatable compared to squid tissue. Juvenile A. parvula were eaten at a significantly greater rate than adults. Sea hare ink did not deter some fishes, which consumed both de-inked and untreated sea hares. Predation by fishes was similar in adjacent habitats, but varied between sites, and was not restricted to $A$. parvula as reef fishes also ate juvenile $A$. dactylomela of equivalent size. The benefit $A$. parvula gain from acquiring algal secondary metabolites is unclear, as these compounds appear ineffective as defences against some fishes. A. parvula may sequester algal secondary metabolites as part of a broader defensive strategy that includes crypsis and escape movements.
\end{abstract}

KEY WORDS: Herbivore - Fish predation - Cost/benefit · Fitness - Diet - Chemical defence · Sea hare $\cdot$ Red algae $\cdot$ Aplysia $\cdot$ Delisea $\cdot$ Laurencia $\cdot$ Ulva

\section{INTRODUCTION}

Sea hares are herbivorous opisthobranch molluscs that acquire and store algal secondary metabolites that

${ }^{*}$ Present address: Department of Biological Science, University of Wollongong, New South Wales 2522, Australia.

E-mail: cary@uow.edu.au may act as chemical defences against predators (Carefoot 1987, Faulkner 1992). In order to evaluate the costs and benefits of the acquisition of secondary metabolites to sea hares it is necessary to measure the trait itself (see Rogers et al. 2000a), and the fitness of individuals under selective pressure (Simms 1992). Appropriate measures of the selective advantage or disadvantage of this trait in sea hares include variation in fitness com- 
ponents (growth, survivorship and fecundity) when fed chemically distinct host algae, and rates of predation on sea hares with different acquired algal metabolites. The fitness of an organism is defined as the lifetime reproductive success of an individual relative to others in the population, and is a difficult property to measure (Brodie et al. 1995). However, short-term estimates of fitness can be obtained by quantifying fitness components (fecundity and survivorship) and performance measures (consumption, growth and conversion efficiency), all of which are referred to as performance herein. Evaluation of the performance of sea hares fed different algae allows assessment of variation in the fitness of these molluscs as a function of diet, and is an indirect measure of their response to sequestered secondary metabolites (as other factors may also vary between algal diets). The effects of predation on fitness are more easily determined as variation in survivorship between sea hares with different types or levels of acquired algal metabolites.

The growth of sea hares has been investigated in numerous studies (reviewed by Carefoot 1987) and is affected by diet quality and quantity, sea hare size and age, and the physical environment. Juvenile sea hares generally grow best on the algae they occur on in the field (i.e. host plants), with poor or negative growth on other diets (Pennings 1990a, Paul \& Pennings 1991). Adult sea hares usually have broader diets, although growth is often best on algae they consumed as juveniles (Carefoot 1987, Pennings 1990a,b). Sea hares are highly fecund and lay egg strings which contain millions of eggs (Kandel 1979, Carefoot 1987). Egg production has been found to vary with algal diet and body size in several species of sea hare (Carefoot 1987, Yusa 1994, Palatzidis et al. 1996), although how this relates to the acquisition of secondary metabolites is unknown.

Early studies of natural products from sea hares reported toxic or detrimental effects on test organisms (reviews by Carefoot 1987, Faulkner 1992, Avila 1995), while sea hare secretions coated onto normally palatable foods made them distasteful to sea gulls (Ambrose et al. 1979, Dimatteo 1981). Similar results were obtained when pieces of sea hare flesh or whole individuals were offered to crabs, reef fishes and anemones (Pennings 1994, Nolen et al. 1995). These results indicate that sea hares are generally unpalatable to some predators and possess deterrent secretions. However, other studies using co-occurring carnivores (Pennings 1990a,c, Rogers et al. 2000b) reached different conclusions. Co-occurring predators were not always deterred by secretions (Pennings 1990a), and some readily consumed sea hares regardless of secretions (Pennings 1990c, Rogers et al. 2000b). This disparity in results may be due to 3 reasons: poor choice of predators by earlier researchers which were not supported by field observations, use of isolated tissues/secretions as opposed to live sea hares, or ontogenetic differences in the susceptibility of sea hares to predators (most studies used adults in their experiments).

Like many other opisthobranchs, sea hares have multiple defences against predation including physical, behavioural and chemical strategies (Carefoot 1987, Karuso 1987, Faulkner 1992, Johnson \& Willows 1999). Physical and behavioural strategies include crypsis and movement, and these are the primary means for avoiding predators (Walters \& Erickson 1986, Johnson \& Willows 1999). If attacked, sea hares can release ink, which serves to startle and/or debilitate a predator, while further physical contact can initiate the release of opaline secretion (Walters \& Erickson 1986, Carefoot 1987, Carefoot et al. 1999, Johnson \& Willows 1999).

The chemical defences of sea hares are those of most interest in this study because they may be associated with the acquisition of algal secondary metabolites. Chemical defences in sea hares consist of ink and opaline secretions and, possibly, their skin, and mucous secretions which coat the skin. Secondary metabolites from Delisea pulchra and Laurencia obtusa have been detected in the mucous, skin and opaline secretions of Aplysia parvula (de Nys et al. 1996, Rogers et al. 2000a), which is consistent with a defensive role for acquired metabolites. A. parvula also differentially accumulate high concentrations of the metabolites palisadin $\mathrm{A}$ and furanone 3 from these red algae (Rogers et al. 2000a). Ginsburg \& Paul (2001) found A. parvula fed the chemically rich red alga Portieria hornemannii were unpalatable to reef fishes, whereas conspecifics fed the chemically poor red alga Acanthophora spicifera were readily eaten. In contrast to this evidence for a defensive role for algal metabolites acquired by sea hares, Pennings (1994) found variable results when comparing the palatability of skin tissue, ink and opaline secretions from 4 species of sea hare against crabs and fishes, and suggested that acquired algal metabolites play no part in defence. However, in an earlier study Pennings (1990a) found that chemically depauperate Aplysia californica were rejected and regurgitated less often by some fishes than chemically rich conspecifics. These conflicting results obscure whether acquired algal metabolites serve as chemical defences in sea hares against co-occurring predators.

This study investigates (1) how algal diet affects the performance of Aplysia parvula, and (2) the potential defensive benefits to $A$. parvula of acquired algal metabolites. Consumption, growth, conversion efficiency, survivorship and egg production were simultaneously measured for sea hares fed Delisea pulchra or Laurencia obtusa. In addition, the effects on performance of 
diet-switching, sea hare size, epiphytes on dietary algae, and the presence of conspecifics were investigated. To assess the effects of predators, A. parvula were offered to reef fishes along with squid tissue in field experiments. The first aim was to determine if chemically rich sea hares were consumed less than chemically poor sea hares (raised on a diet of Ulva sp., which lacks known secondary metabolites), and if sea hares with different acquired metabolites (from $L$. obtusa vs D. pulchra) were consumed at different rates. The second aim was to determine if $A$. parvula reached a size-escape from fishes. The third aim was to determine if predation varied between habitats and sites. The fourth aim was to determine if sea hares lacking ink/opaline were consumed more than sea hares possessing the ability to release these secretions. The fifth aim was to determine if $A$. parvula were more vulnerable to predation by fishes than the co-occurring sea hare A. dactylomela with a similar dietary history.

\section{MATERIALS AND METHODS}

Collection of Aplysia parvula and general techniques. The $A$. parvula used in experiments were collected from Delisea pulchra or Laurencia obtusa in situ by SCUBA diving. Sea hares were collected from $D$. pulchra at Bare Island, Congwong Bay and Cruwee Cove, and from L. obtusa at Shark Bay and Parsley Bay, near Sydney, Australia. Sea hares brought into the laboratory from the field may experience high levels of stress during capture, transportation and introduction into an aquarium system, which causes mortality. To minimise non-treatment effects on the survivorship of $A$. parvula in this study, methods were employed that ensured the sea hares used in experiments were in good condition. Sea hares were individually removed from host algae in the field, placed into a 2.51 plastic jar, then taken to the laboratory where they were held in $10 \mathrm{l}$ aquaria which formed part of a 40001 recirculating seawater system. The recirculating system incorporated a protein skimmer, bio-filter, sand filter and ozone treatment, ensuring good water quality. Sea hares were maintained on a diet of the alga they were collected from, which was supplied ad libitum. Sea hares were typically held for a period of 1 to 2 wk before experiments, to allow them to acclimatise to captivity. Aquaria were subject to the ambient diel light cycle, and water temperatures ranged from 19 to $21^{\circ} \mathrm{C}$ during experiments (see Table 1 ).

Performance experiments were conducted in 251 aquaria divided into a honeycomb of 20 compartments (each containing about 1 l) by plastic sheets. Each compartment was supplied with flowing seawater. Treatments were randomly allocated amongst compart- ments in aquaria. Dietary algae were supplied in excess to consumption, and algae was changed every $3 \mathrm{~d}$, and the aquaria cleaned. The apical parts of algae were used in experiments, as these are preferentially consumed by A. parvula (C.N.R. unpubl. data). Algae were blotted dry on paper towel and weighed (to $0.001 \mathrm{~g}$ wet $\mathrm{wt}$ ), before and after placement in experiments. Autogenic controls to measure changes in algal mass unrelated to consumption by sea hares were incorporated into all experiments ('controls' in Table 1). Sea hares were weighed (to $0.001 \mathrm{~g}$ wet wt) at the start and conclusion of each experiment (or earlier if they died). Egg strings were collected during the cleaning of aquaria and weighed to $0.001 \mathrm{~g}$ wet wt.

Performance experiments. The performance (consumption, growth, rate of egg production, conversion efficiency and survivorship) of Aplysia parvula-fed host algae was measured in 4 laboratory experiments. Because sea hares undergo a gradual transition between the juvenile and adult stages, the size of sea hares used in experiments is important. Sea hares must be young enough at the commencement of experiments to have growth potential in a reasonable time period (i.e. not at the plateau of the growth curve), yet also be capable of reproduction so fecundity can be measured. Hence, some compromise was required between the most desirable size for measuring growth and that needed to measure fecundity. For A. parvula the size that most suited these requirements for this study was sea hares of 0.5 to $1 \mathrm{~g}$ wet wt. Individuals of this size regularly produce egg strings but still grow quickly.

Aplysia parvula switched between diets of host algae consume less and have lower growth compared to conspecifics accustomed to that diet (Rogers et al. 1995). This effect was further investigated here by feeding A. parvula collected from Laurencia obtusa a diet of either L. obtusa or Delisea pulchra and measuring their performance. The effects of conspecifics on performance was also examined by maintaining single and paired sea hares for each diet treatment. Only the faster growing A. parvula, collected from L. obtusa (Rogers et al. 1995) were examined in Expt 1, as the aim was to measure the detrimental effects of a $D$. pulchra diet on sea hares that were unaccustomed to this alga.

The second experiment examined the effects of sea hare size and epiphytes on the performance of Aplysia parvula collected from Delisea pulchra. Small and large sea hares were used according to the design in Table 1. In this experiment sea hares were fed $D$. pulchra with or without a covering of epiphytic algae. Epiphytised thalli of $D$. pulchra were characterised as having a dense cover of red, green and brown algae by visual inspection, whereas 'clean' thalli were mostly 
Table 1. Aplysia parvula. Experimental designs for effects of diet on performance of sea hares. Expt 1 examined effect of switching diet and of conspecifics on performance, Expt 2 effect of sea hare size and epiphytes, and Expts 3 and 4 sea hare performance when fed original host alga in absence ('single') or presence ('paired') of conspecifics

\begin{tabular}{|c|c|c|c|c|c|}
\hline Expt & Date & Treatment & $\begin{array}{c}\text { Duration } \\
\text { (temperature) }\end{array}$ & $\begin{array}{l}\text { No. of } \\
\text { replicates } \\
\text { (controls) }\end{array}$ & $\begin{array}{l}\text { Initial size } \\
\text { (g wet wt) }\end{array}$ \\
\hline (1) Diet \& conspecifics & Apr 1997 & $\begin{array}{l}\text { Delisea pulchra } \\
\text { Laurencia obtusa }\end{array}$ & $\begin{array}{l}22 \mathrm{~d} \\
\left(21^{\circ} \mathrm{C}\right)\end{array}$ & $\begin{array}{l}\text { 10, pairs } 20(3) \\
10, \text { pairs } 20(3)\end{array}$ & $\begin{array}{l}1.33 \pm 0.06 \\
1.31 \pm 0.12\end{array}$ \\
\hline $\begin{array}{l}\text { (2) Size \& epiphytes } \\
\text { (Delisea pulchra) }\end{array}$ & Oct 1995 & $\begin{array}{l}\text { Small } \\
\text { Large }\end{array}$ & $\begin{array}{c}13 \mathrm{~d} \\
\left(20^{\circ} \mathrm{C}\right)\end{array}$ & $\begin{array}{l}5(3) \\
5(3)\end{array}$ & $\begin{array}{l}0.32 \pm 0.07 \\
1.17 \pm 0.15\end{array}$ \\
\hline $\begin{array}{l}\text { (3) Host \& conspecifics } \\
\text { (Delisea pulchra) }\end{array}$ & Aug 1995 & $\begin{array}{l}\text { Single } \\
\text { Paired }\end{array}$ & $\begin{array}{c}22 \mathrm{~d} \\
\left(19^{\circ} \mathrm{C}\right)\end{array}$ & $\begin{array}{c}5(3) \\
10(3)\end{array}$ & $1.21 \pm 0.28$ \\
\hline $\begin{array}{l}\text { (4) Host \& conspecifics } \\
\text { (Laurencia obtusa) }\end{array}$ & Mar 1997 & $\begin{array}{l}\text { Single } \\
\text { Paired }\end{array}$ & $\begin{array}{c}18 \mathrm{~d} \\
\left(21^{\circ} \mathrm{C}\right)\end{array}$ & $\begin{array}{l}10(3) \\
20(3)\end{array}$ & $0.57 \pm 0.04$ \\
\hline
\end{tabular}

free of epiphytes. Clean D. pulchra thalli were used for diet treatments in all other performance experiments done here.

Expts 3 and 4 examined the performance of Aplysia parvula on the host alga (Delisea pulchra or Laurencia obtusa) from which they were collected in the field (Table 1). Treatments consisted of single or paired individuals to evaluate the effects of conspecifics on performance. The sea hares fed L. obtusa in Expt 4 were initially smaller than those fed $D$. pulchra in Expt 3. These experiments are included to show the highest measured performance of sea hares in the laboratory, to demonstrate an apparent trade-off in sea hares fed L. obtusa, and for comparison of sea hare performance on their original host plants.

Data from all experiments were standardised for variation in the size of sea hares and time. Consumption data were divided by the duration of measurements (in d) giving mass loss as g algal wet wt $\mathrm{d}^{-1}$. Egg production was summed for the duration of each experiment, then divided by the initial weight of the sea hare(s), then further divided by the duration in $\mathrm{d}$. Egg production is thus expressed as wet wt of egg string produced (mg) divided by the wet wt of the individual (g) per day. Growth is expressed as the percentage change in sea hare weight per $d$, calculated by dividing the change in sea hare weight by the initial weight of the sea hare(s), then further dividing by the duration in d. Conversion efficiency was calculated by summing the change in sea hare(s) weight and total egg production, then dividing by the total amount of algae consumed (adjusted for autogenic changes).

Egg string measurements. The characteristics of egg strings were evaluated for adult Aplysia parvula fed either Delisea pulchra or Laurencia obtusa for at least 2 wk in Expt 1 described above. Egg strings were collected from 5 pairs of sea hares for each diet, with 15 replicate egg strings examined in total for each diet.
All eggs had been fertilised and most had begun development, as determined by comparison with the description by Kandel (1979). Egg strings were measured using a compound microscope and eyepiece micrometer. The number of eggs per capsule was counted for 5 replicate capsules per egg string (selected haphazardly), then averaged to gain the mean number for that egg string. The number of eggs per millimetre was evaluated by counting along a $200 \mu \mathrm{m}$ length of each egg string and multiplying by 5. Capsule volume was assessed by measuring the length and width of capsules selected haphazardly for each egg string, then using the formula for a cylinder to calculate volume (capsule shape approximated that of a cylinder). Where capsules of different sizes occurred, haphazardly selected large and small capsules were measured for the same egg string.

Predation by fishes. Predation by fishes on sea hares was examined in 5 field experiments conducted during daylight. Methods were designed to expose sea hares to natural assemblages of fishes in the habitat they were collected from, and in nearby habitats; to allow fishes to feed without the stress of capture and captivity; and to allow diver-shy species to feed. Except for Expt 3, all $A$. parvula used were adults ( $>1 \mathrm{~g}$ wet $\mathrm{wt}$ ). Details of the design of each experiment are shown in Table 2 and described below. Treatments containing squid mantle tissue were used in all experiments, both to attract carnivorous fishes and ensure they were feeding, and also to provide a known palatable comparison to sea hares.

In Expts 1 and 2, treatments were attached to longlines (5.5 kg Opal fishing line) using fish hooks (\#12 Mustad). Each longline contained 30 hooks spaced at $10 \mathrm{~cm}$ intervals. Equal numbers of replicates for each treatment (Table 2) were randomly placed along each longline following the design formulated prior to the dive, and data were recorded on waterproof paper. Live 
sea hares were attached to hooks passed through the distal end of the foot, the oblong squid pieces (similar in size to the sea hares) were hooked through one end. The results (sea hares present or absent for each hook) were recorded in situ after $2 \mathrm{~h}$, and the remaining sea hares released. When only part of a sea hare remained attached to a fish hook, this was treated as absent. In Expt 3, treatments were individually tethered to a sandstone reef using fish hooks (\#12 Mustad), $20 \mathrm{~cm}$ of fishing line $(5.5 \mathrm{~kg}$ Opal), and colour-coded masonry nails (for each treatment), and then left for 2 h. During Expts 4 and 5, treatments were released directly into the water column on sandstone reefs $(8$ to $10 \mathrm{~m}$ depth) at Congwong Bay. Treatments were offered to fishes one at a time in randomised order, and the result directly observed and recorded. Observations of what fishes fed, and how, were made at the start and finish of tethering experiments, and for the entire duration of Expts 4 and 5.

Tethering control experiment: It is possible that sea hares escaped from hooks during the $2 \mathrm{~h}$ duration of the tethering experiments described above, so a separate control experiment was performed to evaluate this possibility. A longline (with attached fish hooks) was tethered on a barren area of sandstone reef at Long Bay, near Sydney, and 20 replicate sea hares were attached to the hooks. The sea hares were then observed for $2 \mathrm{~h}$ (fishes were kept away) to determine if any escaped from the hook, which was attached through their tail.

It is also possible that fishes attacked and removed sea hares from hooks during the tethering experiments and then rejected them without consumption. The immediate area surrounding tethers was checked for this eventuality at the conclusion of experiments, although it is possible that fishes carried sea hares further away. However, when fishes were observed to reject sea hares, this happened quickly after tasting them and it seems unlikely, given this response, a fish would swim some distance with a sea hare in its mouth before spitting it out.

Expt 1: To test if predation on adult Aplysia parvula by fishes varied between chemically rich (Delisea pulchra-fed) versus chemically poor (Ulva sp.-fed) individuals, and between shallow versus deep habitats, live A. parvula and squid mantle tissue were tethered on longlines exposed to reef fishes. The $A$. parvula used were grown on a diet of either D. pulchra or Ulva sp. in the laboratory for $6 \mathrm{wk}$ prior to the experiment. Sea hares fed on Ulva sp. (which lacks secondary metabolites) for this period of time have significantly lower levels $(<1 \%$ dry wt) of total D. pulchra secondary metabolites compared to those fed D. pulchra ( 20\% dry wt) (Rogers et al. 2000a). Two longlines were placed at each depth (Table 2). Longlines were attached to the sandstone reef in urchin barrens at Congwong Bay adjacent to $D$. pulchra beds at 3 to $4 \mathrm{~m}$ depth (shallow) and near sponge gardens at 8 to $10 \mathrm{~m}$ depth (deep).

Expt 2: To test if predation on Aplysia parvula by fishes differed between chemically rich (Delisea pulchra-fed) versus chemically poor (Ulva sp.-fed) individuals, and between different sites (Congwong Bay vs Cruwee Cove), live A. parvula and squid mantle tissue were tethered on sandstone reefs exposed to fishes. The A. parvula used were grown on a diet of either $D$. pulchra or Ulva sp. in the laboratory for $6 \mathrm{wk}$ prior to the experiment. Two replicate longlines were set in barrens areas (5 $\mathrm{m}$ depth) at each site to hold treatments (sea hares fed diets of D. pulchra or Ulva sp., or squid tissue).

Expt 3: To test if predation on Aplysia parvula by fishes was different for juvenile versus adult sea hares, live A. parvula and squid mantle tissue were tethered on sandstone reefs exposed to reef fishes, following the design in Table 2. The sea hares used were collected from Laurencia obtusa at Parsley Bay. Juveniles were $\leq 0.3 \mathrm{~g}$ wet wt in size while adults were 1 to $3 \mathrm{~g}$ wet wt. 
Each A. parvula or squid piece was tethered in urchin barrens areas at 3 to $4 \mathrm{~m}$ depth in Cruwee Cove. Tethers were arranged haphazardly in an area of approximately $5 \mathrm{~m}^{2}$.


Fig. 1. Aplysia parvula. Effects of diet-switching on the performance of sea hares collected from Laurencia obtusa (Expt 1). Treatments include diets of Delisea pulchra (D.p.) or L. obtusa (L.o.) and single or paired sea hares. (A) Mean algal mass loss + SE; controls measured autogenic changes unrelated to consumption; post-hoc differences between means were determined using Tukey's test, and treatments that were significantly different at $\alpha=0.05$ are indicated by different letters above each bar. (B) Mean egg production + SE. (C) Mean growth $+\mathrm{SE}$. (D) Mean conversion efficiency $+\mathrm{SE}$; survivorship is shown in parentheses for each treatment (no. surviving/total). $\mathrm{n}=8$ for single D.p. treatment, $\mathrm{n}=6$ for paired D.p., $\mathrm{n}=9$ for single L.o. and $\mathrm{n}=8$ for paired L.o
Expt 4: To compare predation on Aplysia parvula by fishes between individual sea hares with versus without ink/opaline secretions, live $A$. parvula and squid mantle tissue were exposed to reef fishes by releasing them into the water column. The adult sea hares used were all collected from Delisea pulchra. Individuals for the de-inked treatment were squeezed causing ink/opaline release; this was repeated until no further ink/opaline was secreted. Manipulations were done in the laboratory, then sea hares were taken into the field. De-inked and untreated individuals were released into the water column one at a time, in randomised order (Table 2). Each sea hare was preceded and followed by a piece of squid offered to fishes as a palatable comparison. Sea hares were recorded as eaten only if they were swallowed by a fish. Reef fishes in western Congwong Bay are familiar with divers and often congregate when food is offered. When fishes in one area ceased feeding on the squid pieces or disbanded, the experiment was moved along the reef to another area (with different fishes) and continued, starting with a piece of squid.

Expt 5: To compare predation on Aplysia parvula versus that on A. dactylomela by fishes, live sea hares and squid mantle tissue were exposed to reef fishes by releasing them into the water column. Both species of sea hare were collected from Laurencia obtusa at Vaucluse Bay, and then grown on a diet of this alga for $2 \mathrm{wk}$ prior to the experiment. A. parvula and A. dactylomela acquire similar total concentrations of $L$. obtusa secondary metabolites, but the proportions of accumulated metabolites differ (Rogers et al. 2000a). The A. parvula used in this experiment were adults (mean size $1.563 \pm$ SE $0.054 \mathrm{~g}$ wet wt), while the A. dactylomela were juveniles (mean size $1.782 \pm 0.219 \mathrm{~g}$ wet wt); there was no significant difference in the size of sea hares (Student's $t=-0.999, \mathrm{p}=0.324)$. Sea hares were manipulated prior to use in the experiment, causing them to release ink/opaline secretions, so that possible differences between species in their secretions would not confound the result. The same experimental methodology as in Expt 4 was used. Sea hares were released into the water column one at a time, preceded and followed by a piece of squid. Sea hares were recorded as eaten only if they were swallowed by a fish.

Statistical analyses. Algal mass loss among treatments during Performance Expts 1 and 2 were compared by 2 -factor analysis of variance (ANOVA) with diet and treatment (including controls) as fixed factors. Mean mass loss for each treatment was then compared using Tukey's post hoc tests. Data for growth, egg production and conversion efficiency were analysed using 2-factor ANOVA for the various factors examined in Performance Expts 1 and 2 (see 'Results'). All data were checked for homogeneity of variance using 
Cochran's test, transformed where appropriate, and then re-checked for homogeneity (Underwood 1997). Algal mass loss data in Expts 2, 3 and 4 were not homogeneous after transformation. These experiments had large sample sizes, and ANOVA is considered robust to heterogeneous variances under such circumstances (Underwood 1997), so analyses of these experiments are included here, although significant F-ratios should be interpreted cautiously. Algal mass loss, egg production and conversion efficiency data were $\ln (x)$ or $\ln (1+x)$ transformed. Growth data were transformed using arcsine $\sqrt{\mathrm{p}}$, as they consisted of low-percentage values (Zar 1984). Performance data for Expts 3 and 4 were compared using a Student's $t$-test. Survivorship data was pooled for all performance experiments where sea hares were fed their host alga, and compared using a contingency table and log-likelihood ratio (G-test: Zar 1984). The null hypothesis tested was that survivorship of Aplysia parvula was independent of diet (Delisea pulchra vs Laurencia obtusa).

Experiments investigating the predation of Aplysia parvula by fishes were analysed using contingency tables and G-tests. The null hypotheses tested were that consumption of sea hares was independent of treatments - size, dietary history (Delisea pulchra vs Ulva sp.), the presence/absence of ink/opaline secretions, or sea hare species (Table 2). Similar analyses were performed for data on the number of $A$. parvula eaten for the secondary factors depth/habitat and site (Table 2). Overall consumption of squid by fishes was compared to that of $A$. parvula using a $G$-test on pooled data for all predation experiments. Similar analyses were conducted for consumption of adult A. parvula which had acquired D. pulchra metabolites (in Expts 1, 2 and 4) or Laurencia obtusa metabolites (in Expts 3 and 5). The null hypotheses tested were that consumption by fishes was independent of prey type (squid/sea hares) or algal diet (D. pulchra/L. obtusa).

\section{RESULTS}

\section{Performance experiments}

When sea hares collected from Laurencia obtusa were fed Delisea pulchra in Expt 1 (i.e. switched between diets), there was a significant effect of diet on all performance measures (Fig. 1, Tables 3 \& 4), with sea hares performing substantially better on an L. obtusa diet. Sea hares fed D. pulchra consumed much less, produced fewer eggs and lost weight. A significant interaction between diet and conspecifics occurred for consumption (Fig. 1A, Table 3), while other performance measures were unaffected by conspecifics (Fig. 1, Table 4). Survivorship on both diets was high (Fig. 1D).
Epiphytes had no effect on the performance of Aplysia parvula fed clean versus epiphytised Delisea pulchra during Expt 2 (Fig. 2, Tables 3 \& 5). Large sea hares fed clean algae showed greater variability in consumption rate compared to other treatments (Fig. 2A, Table 3). Epiphytes found on D. pulchra
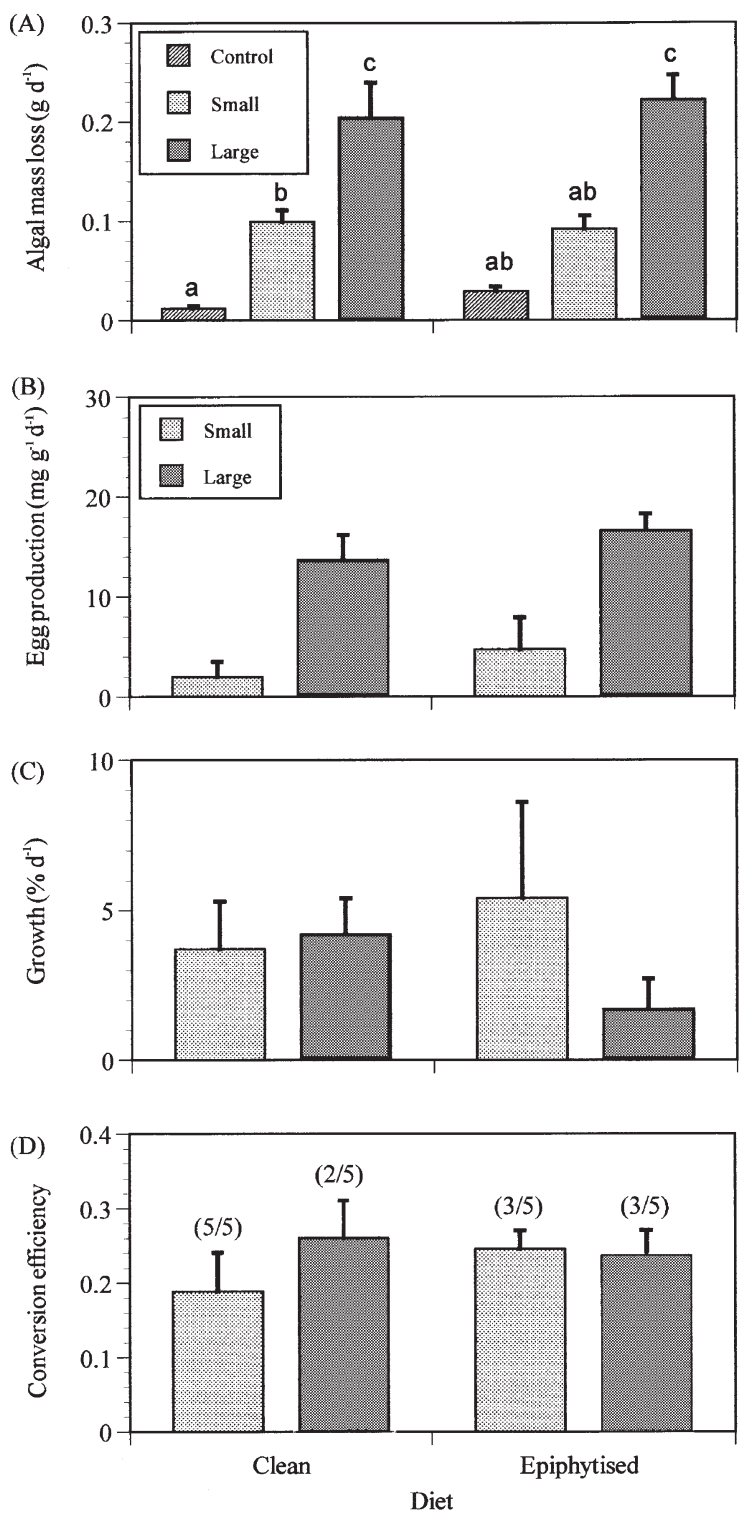

Fig. 2. Aplysia parvula. Effects of epiphytes and body size on the performance of sea hares collected from Delisea pulchra (Expt 2). Treatments included different-sized individuals (small or large) and diets of clean or epiphytised D. pulchra. (A) Mean algal mass loss $+\mathrm{SE}_{\text {; }}$ controls measured autogenic changes; post-hoc differences between means were determined using Tukey's test at $\alpha=0.05$, and bars sharing the same letters were not significantly different at this level. (B) Mean egg production + SE. (C) Mean growth $+\mathrm{SE}$. (D) Mean conversion efficiency $+\mathrm{SE}$; survivorship is shown in parentheses for each treatment (no. surviving/total). $\mathrm{n}=5$ 
Table 3. ANOVA of algal mass loss during Performance Expts 1 and 2. In Expt 1, Aplysia parvula were fed Delisea pulchra or Laurencia obtusa ('Diet'), while 'Treatments' consisted of algal pieces either maintained without sea hares (control), with a single sea hare, or with paired sea hares. In Expt 2, sea hares were fed clean or epiphytised D. pulchra ('Diet'), and 'Treatments' comprised algal pieces either maintained without sea hares (control), with small sea hares, or with large sea hares. Algal mass

loss data were $\ln (x)$-transformed prior to analysis in Expt 1, algal mass loss data from Expt 2 were $\ln (1+x)$-transformed

\begin{tabular}{|c|c|c|c|c|c|c|c|c|}
\hline \multirow{2}{*}{ Source of variation } & \multicolumn{4}{|c|}{ - Expt 1} & & & \multirow{2}{*}{ Expt 2} & \multirow[b]{2}{*}{$\mathrm{p}$} \\
\hline & df & MS & $F$ & $\mathrm{p}$ & $\mathrm{df}$ & MS & & \\
\hline Diet & 1 & 481.7 & 1076.4 & $<0.001$ & 1 & 0.002 & 0.4 & 0.515 \\
\hline Treatment & 2 & 45.6 & 101.8 & $<0.001$ & 2 & 0.254 & 43.9 & $<0.001$ \\
\hline Diet $\times$ Treatment & 2 & 11.0 & 24.7 & $<0.001$ & 2 & 0.002 & 0.4 & 0.700 \\
\hline Error & 321 & 0.45 & & & 106 & 0.006 & & \\
\hline
\end{tabular}

Table 4. Aplysia parvula. ANOVA of performance measures (Expt 1). Single or paired ('Conspecifics') sea hares collected from Laurencia obtusa were fed L. obtusa or Delisea pulchra ('Diet'). Conversion-efficiency data were transformed using $\ln (1+x)$ prior to analysis

\begin{tabular}{|c|c|c|c|c|c|c|c|c|c|c|}
\hline \multirow[t]{2}{*}{ Source of variation } & \multirow[t]{2}{*}{$\mathrm{df}$} & \multicolumn{3}{|c|}{ Egg production } & \multicolumn{3}{|c|}{ Growth } & \multicolumn{3}{|c|}{ Conversion efficiency } \\
\hline & & MS & $F$ & $\mathrm{p}$ & MS & $F$ & $\mathrm{p}$ & MS & $F$ & $\mathrm{p}$ \\
\hline Diet & 1 & 4913.2 & 94.51 & $<0.001$ & 0.024 & 189.07 & $<0.001$ & 11.32 & 14.58 & 0.001 \\
\hline Conspecifics & 1 & 92.2 & 1.77 & 0.194 & $<0.001$ & 0.95 & 0.339 & 0.82 & 1.06 & 0.313 \\
\hline Diet $\times$ Conspecifics & 1 & 0.3 & 0.01 & 0.939 & $<0.001$ & 0.15 & 0.698 & 0.68 & 0.87 & 0.359 \\
\hline Error & 27 & 52.0 & & & $<0.001$ & & & 0.78 & & \\
\hline
\end{tabular}

Table 5. Aplysia parvula. ANOVA of performance measures (Expt 2). Small or large sea hares ('Size') were fed clean or epiphytised Delisea pulchra ('Diet'). Growth data were transformed using arcsine $\sqrt{\mathrm{p}}$ prior to analysis

\begin{tabular}{|c|c|c|c|c|c|c|c|c|c|c|}
\hline \multirow{2}{*}{ Source of variation } & \multirow{2}{*}{$\mathrm{df}$} & \multicolumn{3}{|c|}{ Egg production } & \multicolumn{3}{|c|}{ Growth } & \multicolumn{3}{|c|}{ Conversion efficiency } \\
\hline & & MS & $F$ & $\mathrm{p}$ & MS & $F$ & $\mathrm{p}$ & MS & $F$ & $\mathrm{p}$ \\
\hline Diet & 1 & 39.2 & 1.45 & 0.247 & 2.2 & 0.07 & 0.792 & 0.0012 & 0.14 & 0.718 \\
\hline Size & 1 & 705.7 & 26.02 & $<0.001$ & 51.1 & 1.64 & 0.218 & 0.0043 & 0.49 & 0.493 \\
\hline Diet $\times$ Size & 1 & 0.1 & 0.002 & 0.966 & 33.6 & 1.08 & 0.314 & 0.0075 & 0.85 & 0.372 \\
\hline Error & 16 & 27.1 & & & 31.1 & & & 0.0089 & & \\
\hline
\end{tabular}

Table 6. Aplysia parvula. Egg string measurements. Data for egg strings (mean \pm SE) laid by sea hares fed Delisea pulchra or Laurencia obtusa during Expt 1. Comparison of measurements for each diet was done using a Student's $t$-test. Number of replicates per sample (n) is shown in parentheses

\begin{tabular}{|c|c|c|c|c|}
\hline Measurement & L. obtusa-fed & D. pulchra-fed & $t$ & $\mathrm{p}$ \\
\hline Sea hare size (g wet wt) & $2.337 \pm 0.204(10)$ & $1.425 \pm 0.146(10)$ & 3.64 & 0.002 \\
\hline No. of eggs capsule ${ }^{-1}$ & $1.71 \pm 0.10(15)$ & $1.09 \pm 0.05(15)$ & 5.33 & $<0.001$ \\
\hline No. of eggs $\mathrm{mm}^{-1}$ egg string & $174 \pm 9(15)$ & $130 \pm 6(15)$ & 4.24 & $<0.001$ \\
\hline Capsule vol. $\left(\mathrm{mm}^{3} \times 10^{-3}\right)$ & $2.35 \pm 0.20(28)$ & $1.79 \pm 0.09(27)$ & 2.52 & 0.015 \\
\hline Eggstring width (mm) & $0.72 \pm 0.02(8)$ & $0.67 \pm 0.02(15)$ & 1.54 & 0.138 \\
\hline
\end{tabular}

included Ulva sp., Enteromorpha sp., Colpomenia sp., and filamentous red and brown algae. Sea hare size had a significant effect on consumption (Table 3 ), and also egg production, with large individuals producing more eggs (Table 5). The interaction of diet and size was not significant for any measure. Survivorship during this experiment was relatively low for sea hares collected from D. pulchra (Fig. 2D).
The best performance (highest growth, egg production and survivorship) of Aplysia parvula on the host plants Delisea pulchra or Laurencia obtusa measured during this investigation occurred in separate experiments (3 and 4) which are plotted together to compare diets (Fig. 3). Diet strongly affected the performance of A. parvula. Sea hares from L. obtusa ate more, grew faster and laid more eggs. However, the conversion 
efficiency of sea hares fed L. obtusa was similar to sea hares fed D. pulchra (Fig. 3D). The presence of conspecifics significantly affected egg production and growth of sea hares fed L. obtusa in Expt 4, although conversion efficiency was similar between single and paired sea hares (Fig. 3). There was no effect of conspecifics for sea hares fed D. pulchra. Survivorship of sea hares in both experiments was high (Fig. 3D). Overall experiments in which sea hares were fed host algae, the survivorship of $A$. parvula fed D. pulchra (52 of 65 surviving the experimental duration) was significantly lower than that of sea hares fed L. obtusa (57 of 60$)(G=6.77,0.01<\mathrm{p}<0.005)$.

The number of eggs per capsule, number of eggs $\mathrm{mm}^{-1}$ egg string, and capsule size were significantly different for sea hares fed diets of Delisea pulchra versus Laurencia obtusa (Table 6). Aplysia parvula fed L. obtusa were significantly larger than those fed D. pulchra; they laid more eggs per capsule (in bigger capsules) and consequently had significantly more eggs per $\mathrm{mm}$ of egg string (Table 6). The width of egg strings was similar between diets and comparable with values (0.7 to $0.8 \mathrm{~mm}$ ) for A. parvula in the literature (Carefoot 1987).

\section{Predation by fishes}

The fishes observed to consume sea hares or squid from set lines or when released in the water column included white ear Parma microlepis, yellow fin bream Acanthopagrus australis, snapper Chrysophrys auratus, maori wrasse Ophthalmolepis lineolatus, crimson banded wrasse Pseudolabrus gymnogenis, juvenile eastern blue wrasse Achoerodus viridus, yellow-finned leatherjacket Meuschenia trachylepis and half-banded seaperch Ellerkeldia mccullochi, which were identified from plates in Hutchins \& Swainston (1986). Of these fishes, the damselfish $P$. microlepis and the wrasses $O$. lineolatus and P. gymnogenis consistently attacked and ate sea hares. The other species attacked A. parvula but often spat them out after tasting them. The fishes listed above occurred at both Cruwee Cove and Congwong Bay, in both shallow and deep habitats, except for P. gymnogenis and E. mccullochi which mainly occurred in deeper habitats.

Different species of fishes generally used the same method to feed on sea hares, which involved taking sea hares into their mouth, biting them, then spitting them out. This behaviour was repeated several times before the sea hare was finally swallowed. The initial bite often caused sea hares to ink, the fishes then dissipated this secretion by mouthing then spitting out the sea hare repeatedly. In contrast, squid baits where bitten and quickly swallowed without spitting behaviour. Fishes which rejected sea hares did so immediately fol-

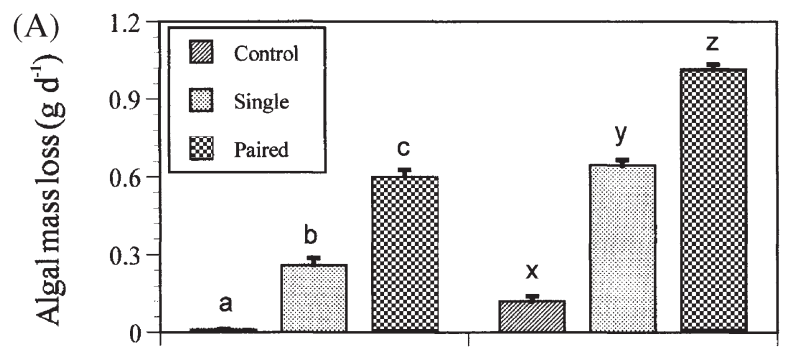

(B)
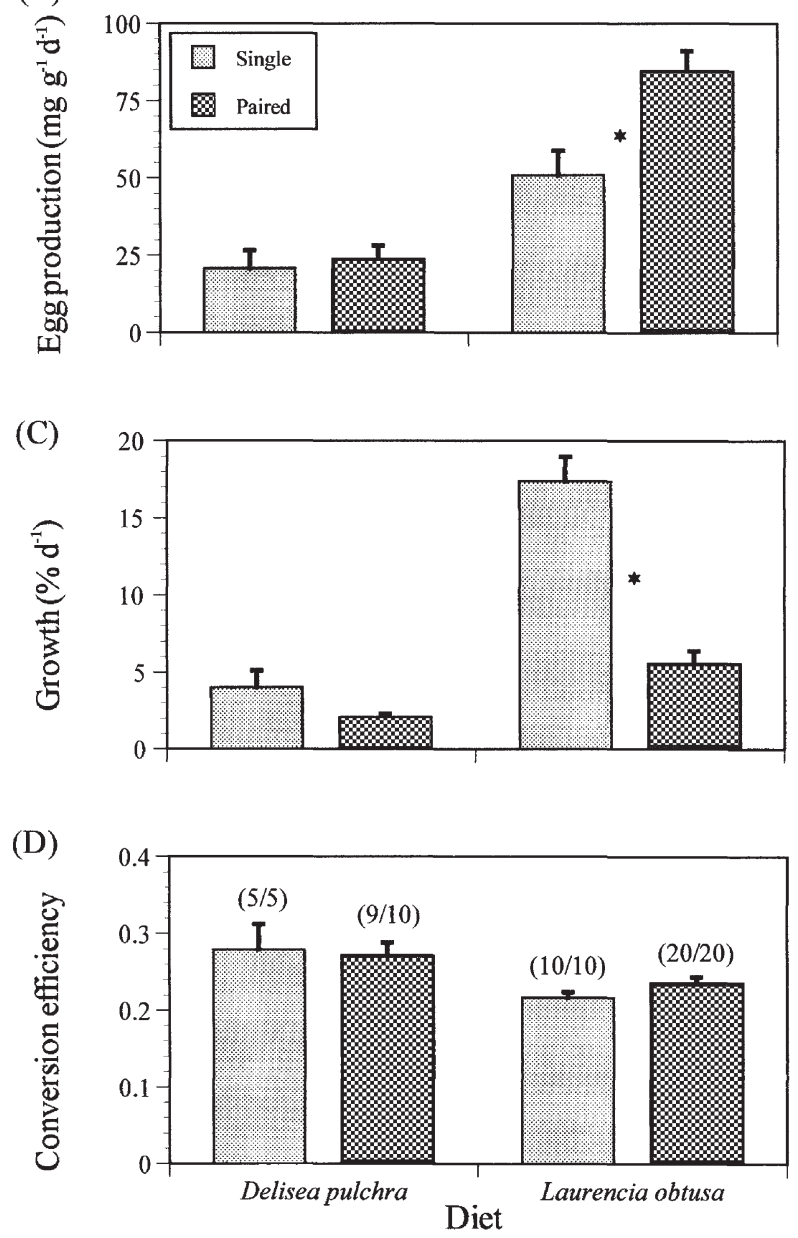

Fig. 3. Aplysia parvula. Performance of sea hares fed host algae (Expts 3 and 4). Diets were Delisea pulchra (D.p.) in Expt 3, and Laurencia obtusa (L.o.) in Expt 4. Treatments within each experiment are single or paired sea hares. (A) Mean algal mass loss $+\mathrm{SE}$; controls measured autogenic changes; results of 1-way ANOVA of mass loss data were D. pulchra diet $F_{2,104}=160.7, \mathrm{p}<0.001$, and L. obtusa diet $F_{2,137}=315.3, \mathrm{p}<0.001$; all treatments were significantly different (within diets only) for mass loss at $\alpha=0.05$ using Tukey's HSD test, as indicated by consecutive letters on the graph. (B) Mean egg production + SE. (C) Mean growth + SE. (D) Mean conversion efficiency $+\mathrm{SE}$; survivorship is shown in parentheses for each treatment (no. surviving/total). $\mathrm{n}=5$ for D.p. diet, $\mathrm{n}=10$ for L.o. diet. Treatments (single vs paired sea hares) were compared within each experiment by Student's $t$-test for egg production, growth and conversion efficiency. ${ }^{*}$ Significant results $(\mathrm{p}<0.05)$ 
Table 7. Predation on Aplysia parvula by fishes. Results for each experiment are shown for sea hare treatments ' $\mathrm{A}$ ' or ' $\mathrm{B}$ ', where values are the number of sea hares eaten/total replicates per treatment. Results of log-likelihood analyses (G-tests) for the number of sea hares consumed are also shown. Delisea pulchra (D.p.)-fed sea hares; Ulva sp. (U.sp.)-fed sea hares; Laurencia obtusa (L.o.)-fed sea hares; ${ }^{*}$ significant results

\begin{tabular}{|llrrrl|}
\hline \multirow{2}{*}{ Expt } & Comparison & 'A' & 'B' & $G$ & $\mathrm{p}$ \\
\hline 1 & D.p.-fed vs U.sp.-fed & $13 / 40$ & $17 / 40$ & 0.86 & $>0.25$ \\
& Shallow vs Deep & $11 / 40$ & $19 / 40$ & 3.44 & $>0.05$ \\
2 & D.p.-fed vs U.sp.-fed & $8 / 27$ & $7 / 28$ & 0.15 & $>0.50$ \\
& Congwong Bay vs Cruwee Cove & $12 / 27$ & $3 / 28$ & 8.29 & $<0.005^{*}$ \\
3 & Juvenile vs Adult & $17 / 20$ & $4 / 20$ & 18.43 & $<0.001^{*}$ \\
4 & Untreated vs De-inked & $7 / 20$ & $9 / 20$ & 0.42 & $>0.50$ \\
5 & A.parvula vs A. dactylomela & $11 / 20$ & $15 / 20$ & 1.78 & $>0.10$ \\
Overall & Aplysia parvula vs Squid & $93 / 235$ & $127 / 177$ & 43.03 & $<0.001^{*}$ \\
& D.p.-fed vs L.o.-fed & $28 / 87$ & $15 / 40$ & 0.34 & $>0.50$ \\
\hline
\end{tabular}

\section{DISCUSSION}

\section{Effects of diet on performance}

The performance of Aplysia parvula fed different diets varies in proportion with their acquisition of secondary metabolites from each seaweed (Rogers et al. 2000a), which agrees with the cost component of current hypotheses for chemical defence (Berenbaum 1995). Sea hares fed a diet of Laurencia obtusa performed better than those fed Delisea pulchra (Figs. 1 \& 3). A. parvula consumed smaller quantities of D. pulchra, yet sea hares of D. pulchra origin did grow and pro-

lowing the first bite, or after closely approaching and investigating the sea hare, suggesting that some fish recognised $A$. parvula as unpalatable either visually or by smell.

In the tethering control experiment, only 1 out of 20 sea hares escaped from the hooks over $2 \mathrm{~h}$. The sea hare that escaped did not crawl far (about $70 \mathrm{~cm}$ after $1 \mathrm{~h}$ ) from the longline, so the investigation of the area surrounding the longlines that was done at the conclusion of the tethering experiments would have located sea hares which had escaped (none were found).

This investigation of predation on Aplysia parvula by fishes showed clear patterns of consumption. Comparison of sea hares fed a chemically rich diet (Delisea pulchra) versus a diet lacking secondary metabolites (Ulva sp.) in Expts 1 and 2 indicated no difference in predation rates in either case (Table 7). There was a marginal difference in the number of sea hares eaten in shallow versus deep habitats (Expt 1), with more sea hares eaten at greater depth. The number of sea hares eaten by fishes at different sites (Expt 2) was significantly different, with more sea hares consumed at Congwong Bay. In Expt 3, juvenile sea hares were consumed at a significantly greater rate $(85 \%$ eaten over $2 \mathrm{~h})$ compared to adults (20\% eaten; Table 7 ). There was no difference in the number of de-inked versus untreated A. parvula eaten (Expt 4: Table 7). Juvenile A. dactylomela which had sequestered Laurencia obtusa metabolites were consumed at a similar rate to adult $A$. parvula of equivalent size (Expt 5). Overall there was a significant difference in the consumption of A. parvula (39.6\% eaten) compared to squid (71.8\% eaten). Thus $A$. parvula are less palatable than squid, but are nonetheless consumed by some fishes. Across experiments, consumption by fishes of adult $A$. parvula with $D$. pulchra metabolites (32.2\% eaten) was not significantly different from that of conspecifics which had acquired L. obtusa metabolites (37.5\% eaten; Table 7). duce eggs, and surprisingly had a similar conversion efficiency to conspecifics fed L. obtusa (Figs. $2 \& 3$ ). This difference in performance correlates with lower levels of acquisition from L. obtusa, in which total metabolites range from 2 to $3.5 \%$ of sea hare dry wt, versus D. pulchra, in which total metabolites range from 5 to $22 \%$ dry wt (Rogers et al. 2000a).

Epiphytes had little effect on the performance of sea hares, even in conjunction with a poor macroalgal diet (Delisea pulchra), in contrast to the argument that small herbivores often enhance their diet with epiphytes (D'Antonio 1985, Brawley 1992). This result is consistent with the data of Rogers et al. (1995), who found that feeding Aplysia parvula mixed diets did not increase growth compared to feeding them host algae alone, and the results of Poore \& Steinberg (1999) for amphipods. Aplysia parvula eat a variety of algae, especially Rhodophytes, but inhabit only a few species including D. pulchra and Laurencia obtusa near Sydney (C.N.R. unpubl. data). While L. obtusa is a good diet sustaining high growth and reproductive output, D. pulchra is less so, and A. parvula may inhabit this alga for other reasons such as refuge value (e.g. Hay et al. 1989), resource availability (Rogers et al. 1995), or to obtain secondary metabolites which deter some natural enemies. Other species of sea hares grow best on algae they occur on in the field (Carefoot 1987, Pennings 1990b, Paul \& Pennings 1991). The results for L. obtusa match this pattern, while in comparison $D$. pulchra is a poor diet.

Negative effects of diet-switching on performance have been reported for herbivorous insects (Scriber 1981, Stockhoff 1992, Tikkanen et al. 2000) and sea slugs (Trowbridge 1991), suggesting that for some small herbivores changing host plants carries a fitness cost. Rogers et al. (1995) found that Aplysia parvula grow poorly when switched between host algae, and other studies have also shown dietary conditioning in 
sea hares (reviewed by Carefoot 1987). A supplementary experiment was conducted in this study (Expt 1), to measure the performance of sea hares switched to a diet of Delisea pulchra from a superior diet of Laurencia obtusa. We suspected that such a change in diet would reduce not only growth, but immediately affect egg production. Since adult $A$. parvula have a short lifespan (estimated at $<6$ mo from field surveys: C.N.R. unpubl. data) any prolonged reduction in fecundity would greatly lower fitness. Sea hares fed D. pulchra performed poorly compared to conspecifics fed $L$. obtusa, as expected (Fig. 1), and egg production was significantly reduced (on average $87 \%$ lower) in sea hares fed $D$. pulchra (Fig. 1B). This disparity in egg production is intriguing; as all sea hares were adults and of similar dietary history, the reason for this drop in egg production is unknown. An interesting contrast is also apparent in the performance of sea hares of different host plant origins when fed D. pulchra (Figs. 1-3). Sea hares collected from $D$. pulchra can grow (2 to $5 \%$ $\mathrm{d}^{-1}$ ) and produce small quantities of egg strings (10 to $25 \mathrm{mg} \mathrm{g}^{-1} \mathrm{~d}^{-1}$ ) on this diet (Figs. $2 \& 3$ ), while sea hares collected from $L$. obtusa lose weight $\left(-1 \% \mathrm{~d}^{-1}\right)$, and lay fewer eggs ( 2 to $8 \mathrm{mg} \mathrm{g}^{-1} \mathrm{~d}^{-1}$ ) when fed $D$. pulchra (Fig. 1). These results suggest that $A$. parvula may adapt to their host algae and that switching diets requires physiological or metabolic changes. An alternative explanation is that $D$. pulchra deterred feeding, and the small quantities eaten had a detrimental effect on performance. Either way, A. parvula collected from D. pulchra perform better on this alga than sea hares collected from L. obtusa. Hence, diet-switching has implications for experimental manipulations which involve diet treatments, as some sea hares may always perform poorly on non-host plants.

Several processes could restrict Aplysia parvula to a specific diet, including physiological changes (metabolic conditioning) or development of a taste for an alga (preferential conditioning). This may occur during the recruit and juvenile stages when sea hares start to consume a host alga (as argued for the ascoglossan Placida dendritica: Trowbridge 1991). Evidence suggesting that metabolic conditioning may cause the diet-switching effects in $A$. parvula includes the poor performance of sea hares switched between host algae compared to conspecifics fed their original host (Rogers et al. 1995; present Figs. 1 \& 3). Secondly, the sequestration of algal metabolites by $A$. parvula varies greatly between $D$. pulchra (up to $22 \%$ dry wt) and Laurencia obtusa (up to $3.5 \%$ dry wt) after $40 \mathrm{~d}$ (Rogers et al. 2000a). This variation in acquisition may reflect different physiological treatment of secondary metabolites from each alga. Conditioning to diets with and without alkaloids has been found in beetle larvae (Dobler \& Rowell-Rahier 1994), with larvae performing best on a diet lacking alkaloids. Sea hares unaccustomed to D. pulchra metabolites, like those collected from $L$. obtusa, may be less capable of metabolising these compounds and reduce their consumption. Our results suggest switching host algae may be costly for A. parvula, with significant consequences for fitness given their short benthic lifespan near Sydney.

Egg string production by single and paired sea hares was greater for a diet of Laurencia obtusa (50 to $85 \mathrm{mg}$ $\mathrm{g}^{-1} \mathrm{~d}^{-1}$ ) compared to Delisea pulchra (20 to $25 \mathrm{mg} \mathrm{g}^{-1}$ $\mathrm{d}^{-1}$ ) (Fig. 3B). The characteristics of egg strings also varied with diet/body size, with the larger $L$. obtusafed sea hares packing significantly more eggs into an eggstring (Table 6). Hence, sea hares fed L. obtusa are at least 5 times more fecund than those fed $D$. pulchra. Other studies of sea hares have also found reproductive effort to vary with diet (Carefoot 1987). Since conversion efficiencies (growth + egg production/consumption) are similar between diets (Fig. 3D), the most likely explanation for the variation in performance of Aplysia parvula is different levels of consumption of each seaweed.

The lower consumption of Delisea pulchra correlates with the rapid accumulation by sea hares of furanone 3 from this alga (Rogers et al. 2000a). When fed Ulva sp. coated with furanone 3 at concentrations found in $D$. pulchra, Aplysia parvula had lower performance (but not significantly different) than sea hares fed other algal metabolites/extracts (C.N.R. unpubl. data). A. parvula may limit their consumption of $D$. pulchra due to the post-ingestive effects of secondary metabolites, as reported for other sea hares (Pennings \& Carefoot 1995). Post-ingestive effects vary for different secondary metabolites (Pennings \& Carefoot 1995) and may also vary between the $D$. pulchra and Laurencia obtusa compounds sequestered by A. parvula. Furthermore, high levels of some secondary metabolites from the cyanophyte Lyngbya majuscula have an inhibitory effect on feeding by Stylocheilus longicauda (Nagle et al. 1998). Furanone 3 from D. pulchra may also reduce feeding by A. parvula, as do apakaochtodene A and B from the alga Portieria hornemannii in Guam (Ginsburg \& Paul 2001). One possible explanation is that high sequestration of furanone 3 causes lower consumption because of physiological limitations on processing ingested metabolites. Such a process would allow greater consumption of L. obtusa, as compounds from this seaweed are sequestered in lower quantities by A. parvula.

The size of sea hares used in experiments affected consumption and growth rates, as has been found for other species (Carefoot 1987), although this effect was noticeable only for sea hares fed Laurencia obtusa (Table 1, Figs. 1C \& 3C). Aplysia parvula fed Delisea pulchra grew at a similar rate regardless of initial size 
(Figs. 2C \& 3C). Conspecifics had a detectable effect on fitness in only 1 of 3 experiments (Figs. $1 \& 3$ ). In Expt 3 (Fig. 3), single individuals fed L. obtusa consumed more, grew significantly faster, but laid fewer eggs than paired conspecifics of similar size. Both single and paired treatments had similar conversion efficiencies. This may indicate a trade-off between growth and egg production (A. parvula are unable to self-fertilise but do store sperm from previous matings [Yusa 1996]), which could be expected if paired animals are expending greater energy on reproduction.

\section{Predation by fishes}

Importantly, in the context of this study, there was no quantitative effect of sequestered algal metabolites on predatory fishes, as Aplysia parvula containing high ( $\geq 20 \%$ dry wt) or low ( $<1 \%$ dry wt: Rogers et al. 2000a) levels of Delisea pulchra metabolites were eaten at similar rates. There was also no qualitative effect of acquired algal metabolites with sea hares that had sequestered $D$. pulchra metabolites $(\geq 20 \%$ dry wt) eaten in similar numbers to those with Laurencia obtusa metabolites (2 to 3.5\% dry wt: Rogers et al. 2000a). Indiscriminate predation by fishes was reported for chemically rich versus poor juvenile A. californica (Pennings 1990a) and Stylocheilus longicauda (Pennings et al. 2001). The lack of deterrence by A. parvula with $D$. pulchra or L. obtusa secondary metabolites indicates that these compounds are ineffective as general defences against some fishes, in contrast to evidence for A. parvula with acquired Portieria hornemannii metabolites (Ginsburg \& Paul 2001). Thus, A. parvula gain no additional protection by accumulating high concentrations of $D$. pulchra metabolites, or for the higher cost in performance associated with a diet of D. pulchra.

Most Aplysia parvula were eaten by wrasses and Parma microlepis, which appeared to dissipate the sea hares ink/opaline secretions by repeatedly biting and spitting out this mollusc. Similar behaviour by fishes was reported for A. californica (Pennings 1990a), Stylocheilus longicauda (Paul \& Pennings 1991, Pennings et al. 2001), and the aeolid nudibranch Phestilla sibogae (Gochfeld \& Aeby 1997). The effects of secretions as a defence was variable depending on individual sea hares and the fish which attacked them in each case. There was no difference in predation rates on de-inked versus untreated $A$. parvula, suggesting other factors may make this sea hare unpalatable such as its mucous secretions, or skin. When fishes did reject $A$. parvula, it was done rapidly after the initial bite or inspection (probably by olfactory and visual senses), indicating that the sea hares tasted bad or were recognised as unpalatable.
Juvenile sea hares were consumed in much greater numbers by fishes than adults in this study, suggesting they experience high mortality in the field. There are no similar direct comparisons of adult versus juvenile mortality reported in the literature for sea hares, although Pennings (1990a) showed that juvenile Aplysia californica were highly consumed by some fishes. It is likely that larger sea hares such as A. californica reach a size-escape from fish predation. However, $A$. parvula are small even as adults (generally $<5 \mathrm{~g}$ wet wt near Sydney), hence predation by fishes probably remains an important selective pressure throughout their benthic life. This is the second study to demonstrate that the algal secondary metabolites acquired by A. parvula are ineffective as defences against cooccurring predators. Juvenile A. parvula and other sea hares are also consumed by the pycnogonid Anoplodactylus evansi in eastern Australia, but reach a size-escape from this predator (Rogers et al. 2000b). Predation rates on adult $A$. parvula by fishes were similar to those on juvenile $A$. dactylomela of equivalent size, indicating that some reef fishes near Sydney will consume a range of sea hares. Predation by fishes was similar in different habitats, despite A. parvula occurring mainly on shallow reefs where host algae were most abundant (C.N.R. unpubl. data). The wrasses and damselfish that consume $A$. parvula were observed in all the habitats investigated here (algal beds, barrens and sponge gardens). There was a significant difference in predation rates between sites, possibly due to differences in the fish assemblages present at each site during the experiment. A. parvula were consumed significantly less than squid during experiments. This difference in the palatability to predatory fishes of squid versus sea hares may be caused by numerous factors including toughness, appearance, nutritional quality or smell.

While Aplysia parvula may inhabit chemically rich red algae to obtain secondary metabolites, these host plants also provide refuge for small herbivores (e.g. Hay et al. 1989), and this property could be an important component of host choice by this sea hare. Delisea pulchra and Laurencia obtusa have complex habits which A. parvula exploit as cover during daylight by moving into the enclosed basal parts (Rogers et al. 1998). The performance of $A$. parvula varies greatly between these host algae, yet a poor-quality host like $D$. pulchra which is costly to consume may have compensatory benefits. D. pulchra is abundant and present year-round near Sydney, while in comparison L. obtusa is ephemeral and patchy (C.N.R. unpubl. data). Since suitable host plants may be unpredictable in time and space, the abundant $D$. pulchra may support a greater proportion of the population of $A$. parvula. $D$. pulchra also inhibits feeding by a range of herbivores 
(Steinberg \& van Altena 1992, H. Davies unpubl. data); hence this alga is a relatively secure resource on which sea hares have a reduced likelihood of exploitative competition and consumption by omnivores or large herbivores. Resource security has been argued to be a major influence in host selection by mesograzers (Hay et al. 1988, Hay \& Steinberg 1992); similarly in this case, it may be an important determinant of host choice by A. parvula. Many species of sea hare inhabit and eat chemically rich algae during their juvenile phase, then forage openly as large adults (Carefoot 1987). A. parvula do not grow large enough to escape or deter predatory fishes, hence they remain closely associated with chemically rich algae for the duration of their benthic life. The use of chemically rich algae (as refuges) may be a common strategy amongst sea hares which enhances the survivorship of recruits and juveniles or species which are small as adults.

The algal metabolites acquired by Aplysia parvula may work best when the sea hares are in close association with host plants, not exposed in the open as in the predation experiments done here. Due to their diel movement on these algae (Rogers et al. 1998), A. parvula were rarely visible on either host seaweed during the day compared to at night. This cryptic behaviour in combination with cryptic body colouration may reduce encounters with fishes, and suggests that visual predators are an important selective force (e.g. Stachowicz \& Hay 1999). A. parvula may augment these physical defences (and gain a direct benefit) by incorporating algal secondary metabolites into their skin, mucous and opaline secretions (de Nys et al. 1996, Rogers et al. 2000a), making them unpalatable to some potential predators, as suggested by the rejection behaviour of individual fishes in this study. This deployment of algal secondary metabolites on the body surface may also have indirect benefits by acting as an olfactory camouflage against predators that hunt by smell. Thus, the likely benefits of acquired algal secondary metabolites to $A$. parvula is through their deployment on the body surface, where these compounds may make them less palatable to potential predators or less detectable on host plants. Hence, acquired algal metabolites do not provide immunity from predators for A. parvula, instead they may form one part of a wider defence strategy centred around host plants.

Acknowledgements. The authors thank Jeff Wright and Deborah Rogers for assistance during dives to collect sea hares, and Helen Davies for assistance during dives to conduct the predation experiments. We appreciate comments by S. Pennings and reviewers that improved this manuscript. C.N.R. was supported by an Australian Postgraduate Award and a scholarship from the Centre for Marine Biofouling and Bioinnovation at UNSW during the period of this work. R.d.N. was supported by an Australian Research Council Fellowship. This research was funded by Australian Research Council Grant \#A195300672 to P.D.S.

\section{LITERATURE CITED}

Ambrose HW, Givens RP, Chen R, Ambrose KP (1979) Distastefulness as a defense mechanism in Aplysia brasiliana. Mar Behav Physiol 6:57-64

Avila C (1995) Natural products of opisthobranch molluscs: a biological review. Oceanogr Mar Biol Annu Rev 33:487-559

Berenbaum MR (1995) The chemistry of defense: theory and practice. Proc Natl Acad Sci USA 92:2-8

Brawley SH (1992) Mesoherbivores. In: John DM, Hawkins $\mathrm{SJ}$, Price JH (eds) Plant-animal interactions in the marine benthos. Clarendon, Oxford, p 235-263

Brodie ED, Moore AJ, Janzen FJ (1995) Visualising and quantifying natural selection. Trends Ecol Evol 10:313-318

Carefoot TH (1987) Aplysia: its biology and ecology. Oceanogr Mar Biol Annu Rev 25:167-284

Carefoot TH, Pennings SC, Danko JP (1999) A test of novel function(s) for the ink of sea hares. J Exp Mar Biol Ecol 234:185-197

D'Antonio C (1985) Epiphytes on the rocky intertidal red alga Rhodomela larix: negative effects on the host and food for herbivores. J Exp Mar Biol Ecol 86:197-218

de Nys R, Steinberg PD, Rogers CN, Charlton TS, Duncan MW (1996) Quantitative variation of secondary metabolites in the sea hare Aplysia parvula and its host plant Delisea pulchra. Mar Ecol Prog Ser 130:135-146

Dimatteo T (1981) The inking behaviour of Aplysia dactylomela: evidence for distastefulness. Mar Behav Physiol 7: 285-290

Dobler S, Rowell-Rahier M (1994) Response of a leaf beetle to 2 food plants, only one of which provides a sequestrable defensive chemical. Oecologia 97:271-277

Faulkner DJ (1992) Chemical defences of marine molluscs. In: Paul VJ (ed) Ecological roles of marine natural products. Comstock, Ithaca, NY, p 119-163

Ginsburg DW, Paul VJ (2001) Chemical defenses in the sea hare Aplysia parvula: importance of diet and sequestration of algal secondary metabolites. Mar Ecol Prog Ser 215:261-274

Gochfeld DJ, Aeby GS (1997) Control of populations of the coral-feeding nudibranch Phestilla sibogae by fish and crustacean predators. Mar Biol 130:63-69

Hay ME, Steinberg PD (1992) The chemical ecology of plantherbivore interactions in marine versus terrestrial commmunities. In: Rosenthal GA, Berenbaum MR (eds) Herbivores: their interactions with secondary plant metabolites, Vol. 2. Evolutionary and ecological processes. Academic Press, New York, p 371-413

Hay ME, Renaud PE, Fenical W (1988) Large mobile versus small sedentary herbivores and their resistance to seaweed chemical defences. Oecologia 75:246-252

Hay ME, Pawlik JR, Duffy JE, Fenical W (1989) Seaweedherbivore-predator interactions: host-plant specialization reduces predation on small herbivores. Oecologia 81: $418-427$

Hutchins B, Swainston R (1986) Sea fishes of southern Australia. Swainston Publishing, Perth

Johnson PM, Willows AOD (1999) Defence in sea hares: multiple layers of protection from egg to adult. Mar Freshw Behav Physiol 32:147-180

Kandel ER (1979) Behavioral biology of Aplysia. WH Freeman \& Co., San Francisco 
Karuso P (1987) Chemical ecology of nudibranchs. In: Scheuer PJ (ed) Bioorganic marine chemistry, Vol 1. SpringerVerlag, Heidelberg, p 32-60

Kriegstein AR, Castellucci V, Kandel ER (1974) Metamorphosis of Aplysia californica in laboratory culture. Proc Natl Acad Sci USA 71:3654-3658

Nagle DG, Camacho FT, Paul VJ (1998) Dietary preferences of the opisthobranch mollusc Stylocheilus longicauda for secondary metabolites produced by the tropical cyanobacterium Lyngbya majuscula. Mar Biol 132:267-273

Nolen TG, Johnson PM, Kicklighter CE, Capo T (1995) Ink secretion by the marine snail Aplysia californica enhances its ability to escape from a natural predator. J Comp Physiol A Sens Neural Behav Physiol 176:239-254

Palatzidis S, Yamasaki S, Hirata H, Imai T (1996) Food consumption and growth of Aplysia dactylomela. Suisanzoshoku (Aquaculture, Tokyo) 44:125-131

Paul VJ, Pennings SC (1991) Diet-derived chemical defenses in the sea hare Stylocheilus longicauda. J Exp Mar Biol Ecol 151:227-243

Pauly D, Calumpong H (1984) Growth, reproduction and mortality of the sea hare Dolabella auricularia in the central Visayas, Philippines. Mar Biol 79:289-293

Pennings SC (1990a) Multiple factors promoting narrow host range in the sea hare, Aplysia californica. Oecologia 82: 192-200

Pennings SC (1990b) Size-related shifts in herbivory: specialization in the sea hare Aplysia californica. J Exp Mar Biol Ecol 142:43-61

Pennings SC (1990c) Predator-prey interactions in opisthobranch gastropods: effects of prey body size and habitat complexity. Mar Ecol Prog Ser 62:95-101

Pennings SC (1991) Spatial and temporal variation in recruitment of Aplysia californica: patterns, mechanisms and consequences. J Exp Mar Biol Ecol 146:253-274

Pennings SC (1994) Interspecific variation in chemical defenses in the sea hares. J Exp Mar Biol Ecol 180:203-219

Pennings SC, Carefoot TH (1995) Post-ingestive consequences of consuming secondary metabolites in sea hares. Comp Biochem Physiol C Comp Pharmacol 111:249-256

Pennings SC, Nastisch S, Paul VJ (2001) Vulnerability of the sea hare Stylocheilus longicauda to fish predators: importance of diet and fish species. Coral Reefs 20:320-324

Plaut I, Borut A, Spira ME (1996) Lifetime energy budget in the sea hare Aplysia oculifera. Comp Biochem Physiol A 113:205-212

Poore AGB, Steinberg PD (1999) Preference-performance relationships and effects of host plant choice in an herbivorous marine amphipod. Ecol Monogr 69:443-464

Editorial responsibility: Joseph Pawlik (Contributing Editor), Wilmington, North Carolina, USA
Rogers CN, Steinberg PD, de Nys R (1995) Factors associated with oligophagy in two species of sea hares. J Exp Mar Biol Ecol 192:47-73

Rogers CN, Williamson JE, Carson DG, Steinberg PD (1998) Diel vertical movement by mesograzers on seaweeds. Mar Ecol Prog Ser 166:301-306

Rogers CN, de Nys R, Charlton TS, Steinberg PD (2000a) Dynamics of algal secondary metabolites in two species of sea hare. J Chem Ecol 26:721-744

Rogers CN, de Nys R, Steinberg PD (2000b) Predation on juvenile Aplysia parvula and other small anaspidean, ascoglossan, and nudibranch gastropods by pycnogonids. Veliger 43:330-337

Scriber JM (1981) Sequential diets, metabolic costs and growth of Spodoptera eridania feeding on dill, lima bean, and cabbage. Oecologia 51:175-180

Simms EL (1992) Costs of plant resistance to herbivory. In: Fritz RS, Simms EL (eds) Plant resistance to herbivores and pathogens. University of Chicago Press, Chicago, p 392-425

Stachowicz JJ, Hay ME (1999) Reducing predation through chemically mediated camouflage: indirect effects of plant defences on herbivores. Ecology 80:495-509

Steinberg PD, van Altena I (1992) Tolerance of marine invertebrate herbivores to brown algal phlorotannins in temperate Australasia. Ecol Monogr 62:189-222

Stockhoff BA (1992) Diet-switching by gypsy moth: effects of diet nitrogen history vs switching on growth, consumption, and food utilisation. Entom Exp Appl 64:225-238

Tikkanen O, Niemela P, Keranen J (2000) Growth and development of a generalist insect herbivore Operophtera brumata on original and alternative host plants. Oecologia 122:529-536

Trowbridge CD (1991) Diet specialisation limits herbivorous sea slugs capacity to switch among food species. Ecology 72:1880-1888

Underwood AJ (1997) Experiments in ecology. Cambridge University Press, Cambridge

Walters ET, Erickson MT (1986) Directional control and the functional organisation of defensive responses in Aplysia. J Comp Physiol A 159:339-351

Yusa Y (1994) Size related egg production in a simultaneous hermaphrodite, the sea hare Aplysia kurodai. Publ Seto Mar Biol Lab 36:249-254

Yusa Y (1996) Utilisation and degree of depletion of exogenous sperm in three hermaphroditic sea hares of the genus Aplysia. J Molluscan Stud 62:113-120

Zar JH (1984) Biostatistical analysis, 2nd edn. Prentice-Hall, Englewood Cliffs, NJ

Submitted: May 29, 2001; Accepted: December 7, 2001

Proofs received from author(s): June 6, 2002 